\title{
Mean Platelet Volume in Patients With Obstructive Sleep Apnea Syndrome and Concurrent Hypertension and Diabetes Mellitus
}

\author{
Obstüktif Uyku Apneli ve Eșlik Eden Hipertansiyonlu ve Diabetes Mellituslu \\ Hastalarda Ortalama Trombosit Hacmi
}

\author{
(1) Ayşegül Altıntop Geçkil, (1) Çiğdem Fırat Koca* \\ Malatya Training and Research Hospital, Clinic of Pulmonary Diseases Malatya, Turkey \\ * Malatya Training and Research Hospital, Clinic of Otolaryngology Head and Neck Surgery, Malatya, Turkey
}

\begin{abstract}
Objective: Obstructive Sleep Apnea syndrome (OSAS) is a common disorder affecting especially middle-aged adults. Elevated platelet activation and aggregation have a close relationship with cardiovascular complications. Mean platelet volume (MPV) is a marker of platelet activation. The influence of OSAS on platelet activation is not fully understood subject.

Materials and Methods: One hundred ninety-two patients who were included in this study examined retrospectively with polysomnography. The Apnea-hypopnea index (AHI) above five was accepted as OSAS. The AHI under five was decided as control group. The OSAS group was categorized into three groups according to AHI values. Patients whose AHI was 5-15 decided as mild, 15-30 as moderate, and above 30 was severe group. The control group consist of 28 patients (14.6\%), mild OSAS group consist of 31 patients (16.1\%), moderate OSAS group consist of 42 patients (21.9\%), and severe OSAS group consist of 91 patients (47.6\%). The medical and sleep histories, demographic data, cardiovascular and metabolic histories, drug use of the patients were retrospectively examined. Laboratory analyze consisted of a routine blood evaluation. Hypertension and diabetes mellitus history also investigated.

Results: There were significant differences between the groups in desaturation index, Body Mass index, $\mathrm{AHI}$, minimum oxygen saturation, and arousal $(p<0.001)$. There was no significant difference between the groups in terms of hemoglobin, leukocyte, platelet count, and MPV. Conclusion: We aimed to analyze whether there was a correlation between the level of OSAS and the MPV value and its relationship with cardiovascular diseases. In conclusion, the level of OSAS was not correlated with MPV. This subject should be analyzed by further studies. Keywords: Obstructive sleep apnea, mean platelet volume, cardiovascular
\end{abstract}

Öz

Amaç: Obstrüktif Uyku Apne sendromu (OUAS) özellikle orta yaş erişkinleri etkileyen yaygın bir hastalıktır. Artmış platelet aktivasyon ve agregasyonu ile kardiyovasküler komplikasyonlar arasında yakın bir ilişki mevcuttur. Ortalama trombosit hacmi, platelet aktivasyonunun bir belirtecidir. OUAS'nin platelet aktivasyonu üzerine etkisi tam olarak anlaşılamamış bir konudur.

Gereç ve Yöntem: Bu çalışmaya dahil edilen 192 hasta polisomnografi ile retrospektif olarak incelendi. Apne-hipopne indeksi (AHI) beşin üzerinde olması OUAS olarak kabul edildi. AHI beşin altında olanlar kontrol grubu olarak kararlaştırıldı. OUAS grubu apne-hipopne değerine göre üç gruba ayrıldı. AHI 5-15 arası olanlar hafif, 15-30 arası olanlar orta ve 30 üzeri olanlar ağır grup olarak ayrıldı. Kontrol grubu 28 hastadan $(\% 14,6)$, hafif obstrüktif uyku apne grubu 31 hastadan $(\% 16,1)$, orta obstrüktif uyku apne grubu 42 hastadan $(\% 21,9)$ ve ağır obstrüktif uyku apne grubu 91 hastadan $(\% 47,6)$ oluşuyordu. Hastaların medikal ve uyku hikayeleri, demografik verileri, kardiyovasküler ve metabolik hikayesi, ilaç kullanımı retrospektif olarak incelendi. Laboratuar incelemesi rutin kan değerlendirmesinden oluşuyordu. Hipertansiyon ve diabetes mellitus hikayesi de ayrıca araştırıldı.

Bulgular: Gruplar arasında Desatürasyon indeksi, Vücut Kitle indeksi, $\mathrm{AHI}$, minimum oksijen satürasyonu ve arousal arasında anlamlı fark mevcuttu $(p<0,001)$. Hemoglobin, lökosit, platelet sayısı ve ortalama trombosit hacmi değerlerinde gruplar arasında anlamlı fark yoktu.

Sonuç: OUAS derecesi ile ortalama trombosit hacmi değeri arasında korelasyon olup olmadığını ve kardiyovasküler hastalıklarla olan ilişkisini analiz etmeyi hedefledik. Sonuç olarak OUAS derecesi ile ortalama trombosit hacmi arasında korelasyon mevcut değildi. Bu konu ileri çalışmalarla analiz edilmelidir.

Anahtar Kelimeler: Tıkayıcı uyku apne, ortalama trombosit hacmi, kardiyovasküler 


\section{Introduction}

Obstructive Sleep Apnea syndrome (OSAS) can be defined as recurrent apnea and hypopnea attacks due to occlusion of the upper airways during sleep. It affects especially middleaged adults, $4 \%$ of men and $2 \%$ of women (1). OSAS is an important risk for cardiovascular pathologies and hypertension (2). OSAS is an independent risk factor for cardiac mortality and morbidity. Elevated platelet activation is responsible for the development of cardiovascular complications. There are several studies have studied this relationship in the literature (3-6). Elevated platelet activation is associated with increased platelet volume. Larger platelets have denser granules that are metabolically and enzymatically more active than smaller ones and have increased thrombotic activity (1).

Mean platelet volume (MPV) can be evaluated as a determiner for platelet activation and aggregation. MPV has a strict relationship with cardiovascular pathologies (2). Activation of sympathetic nervous system, endothelial dysfunction, hypoxia, and oxidative stress are accused for the increased Cardiovascular diseases (CVD) occurence in OSAS $(7,8)$.

There are little information about MPV in OSAS. This subject has been becoming popular. In this present study our aim was to investigate the relationship between MPV in OSAS patients and in this context the relationship with cardiovascular pathologies.

\section{Materials and Methods}

\section{A-study design}

In this study our goal is to show the relationship between OSAS, and MPV additionally with cardiovascular pathologies. One hundred ninety-two patients who were included in this study. One hundred ninety-two patients were examined with polysomnography retrospectively. Apnea was defined as complete cessation of airflow for more than 10 seconds, hypopnea was defined as a reduction of more than 30\% in oronasal airflow for at least 10 seconds, and at least 3\% decrease in $\mathrm{SPO}_{2}$ relative to baseline. Apnea-hypopnea index (AHI) was defined as the total number of apneas and hypopneas per hour. The AHI above five (5) was accepted as OSAS. The AHI under five was decided as control group. OSAS group was categorized into three groups according to AHI. The AHI under five was decided as control group. OSAS group was categorized into three groups according to AHI. Patients whose AHI was 5-15 decides as mild, $15-30$ as moderate and above 30 was severe group. Ninety-seven patients (50.5\%) were women and 95 patients (49.5\%) were men. The mean age was $55.8 \pm 10.1$ between groups. The control group consist of 28 patients (14.6\%), mild OSAS group consist of 31 patients (16.1\%), moderate group consist of 42 patients (21.9\%) and severe group consist of 91 patients (47.4\%). The study was created after the ethics committee approval by Malatya Clinical Research Ethics Committee. The records of 192 patients were studied who recruited in the Sleep Disorders Centre of Malatya Training and Research Hospital between June 2017 and March 2018 retrospectively. Exclusion criterias; narcolepsy, Central Sleep Apnea syndrome, drug users such as aspirin, dipiridamol, clopidogrel, heparin, non-steroidal anti-inflammatory drug, alcohol, Hypoxic Lung diseases. The medical and sleep history, demographic datas, cardiovascular and metabolic history, medication use were examined retrospectively. Laboratory evaluation consist of a routine blood examination. Hypertension and diabetic history also investigated. Demographic datas such as age, sex, Body Mass index (BMI) were recorded.

\section{Polysomnography}

Polysomnography was performed using a digital polysomnographic monitor (Alice 6 LDx Diagnostic Sleep System, Philips, Germany). The system consists of four electroencephalography channels, two electrooculography channels, tibial/submental electromyography and electrocardiography as well as monitoring oronasal airflow, thoracic movements, abdominal movements, $\mathrm{SpO}_{2}$ and body position. Polysomnographic records were interpreted manually at 30-second intervals according to the guidelines defined by the American Academy of Sleep Medicine (AASM). The analysis of sleep records was evaluated according to AASM 2012 criteria by an experienced sleep laboratory specialist. Apnea was defined as complete cessation of airflow for more than 10 seconds, hypopnea was defined as a reduction of more than $30 \%$ in oronasal airflow for at least 10 seconds, and at least 3\% decrease in $\mathrm{SpO}_{2}$ relative to baseline. Arousal index was defined as the number of arousal, which was defined as sudden transition to superficial sleep phase or wakefulness during the total sleep period, per hour (arousal/hour). Apnea and hypopnea counts were defined as AHI. According to the severity, patients were classified as mild OSAS (AHI=5-15), moderate OSAS (AHI=15-30), and severe OSAS (AHI>30). Sleep stages were scored following standard criteria with 30-second epochs and were reviewed and verified by a certified sleep physician.

\section{Statistical Analysis}

All data was analyzed with "SPSS 25.0 for Windows" software. Numerical variables were defined as mean \pm standart deviation; categorical variables were defined as percentiles. In a comparision of three or more groups, if the variables fit the normal distribution, one-way ANOVA was used. In comparision of the categorical variables, the multiple comparision chi-square test was used. In post-hoc analysis, Tukey's test was used. All hypotheses were established as two-way, and alpha critical value was accepted as 0.05 .

\section{Laboratory Analysis}

Laboratory results were examined retrospectively. MPV, white blood cell (WBC) count, platelet count, mean corpuscular volume (MCV), hemoglobin $(\mathrm{Hb})$ hematocrit were evaluated. The MPV values ranged between 0 to $99.9 \mathrm{fl}$ in our hematology laboratory.

\section{Results}

Our study included 192 patients. The baseline characteristics of four groups are summarized in Table 1 and 2. The demographic and clinical characteristics of the study group are demonstrated 
in Table 1 and hematologic datas are demonstrated in Table 2. Ninety-seven patients (50.5\%) were women and 95 patients (49.5\%) were men. The mean age was $55.8 \pm 10.1$ between groups. There were no significant differences were found between the groups in terms of age and sex. The AHI under five was decided as control group. OSAS group was categorized into three groups according to $\mathrm{AHI}$. The $\mathrm{AHI}$ under five was decided as control group. OSAS group was categorized into three groups according to AHI. Patients whose AHI was 5-15 decides as mild, 15-30 as moderate and above 30 was severe group. Control group consist of 28 patients (14.6\%), mild OSAS group consist of 31 patients (16.1\%), moderate group consist of 42 patients (21.9\%) and severe group consist of 91 patients (47.4\%). The mean $\mathrm{AHI}$ values were for control group $4.6 \pm 8.8$, mild group $11 \pm 3.6$, moderate group $26.5 \pm 3.9$ and the severe group $66.8 \pm 21.3(p<0.001)$. When the four groups including controls, the severe group had the lowest minimum $\mathrm{SpO}_{2}$ level (control group 85.4 \pm 5.4 , mild

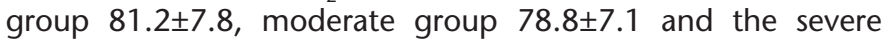
group 71.8 \pm 10.8$)(p<0.001)$. On the other hand hematologic parameters are given in Table 2. MPV levels did not differ between groups (control group 10.2 \pm 0.9 , mild group $10.3 \pm 1$, moderate group $10.3 \pm 0.9$ and the severe group $10.3 \pm 0.9$ ) $(p=0.993)$. There were no significant differences between groups with respect to white blood cells, $\mathrm{Hb}$, platelet count, $\mathrm{MCV}$, hemotocrit. The medical and sleep history, demographic datas, cardiovascular and metabolic history, medication use were examined retrospectively. Laboratory evaluation consist of a routine blood examination. Hypertension and diabetic history also investigated. There were a significant difference in Desaturation index (DI), BMI, $\mathrm{AHI}$, minimum oxygen saturation, arousal between groups ( $p$ 0.001). However, there were no significant differences among groups with regard to diabetes mellitus and hypertension.

\section{Discussion}

OSAS can be defined as; upper airway obstruction episodes during sleep, increased respiratory efforts; intermittent arterial oxygen desaturation. The gold standard diagnostic test is an overnight polysomnography. OSAS is a common disease among the population; nearly affecting $>4 \%$ of males and $2 \%$ of females (9). OSAS patients have a tendency towards cardiovascular morbidity. Platelets has an major role in the cardiovascular disease mechanism. Platelet aggregability is the main factor in Atherosclerotic Vasoocclusive disease pathogenesis and this subject has been searched in OSAS patients (10). Large sized thrombocytes have more granules and thromboxane A2 content and produce extra glycoprotein $\mathrm{Ib}$ and Ilb/IIla receptors; this causes a quick platelet aggregation and makes a strong collagen; may start to thromboembolic events $(8,11-13)$.

The pathogenesis of Cardiovascular disease in OSAS can be analyzed by different, may be interacting mechanisms. These mechanisms consist of sympathetic nervous system overactivity, exaggerated inflammation, endothelial dysfunction, finally insulin resistance and corrupt lipid metabolism. Nena et al. (14) found that MPV and platelet distribution width (PDW) were

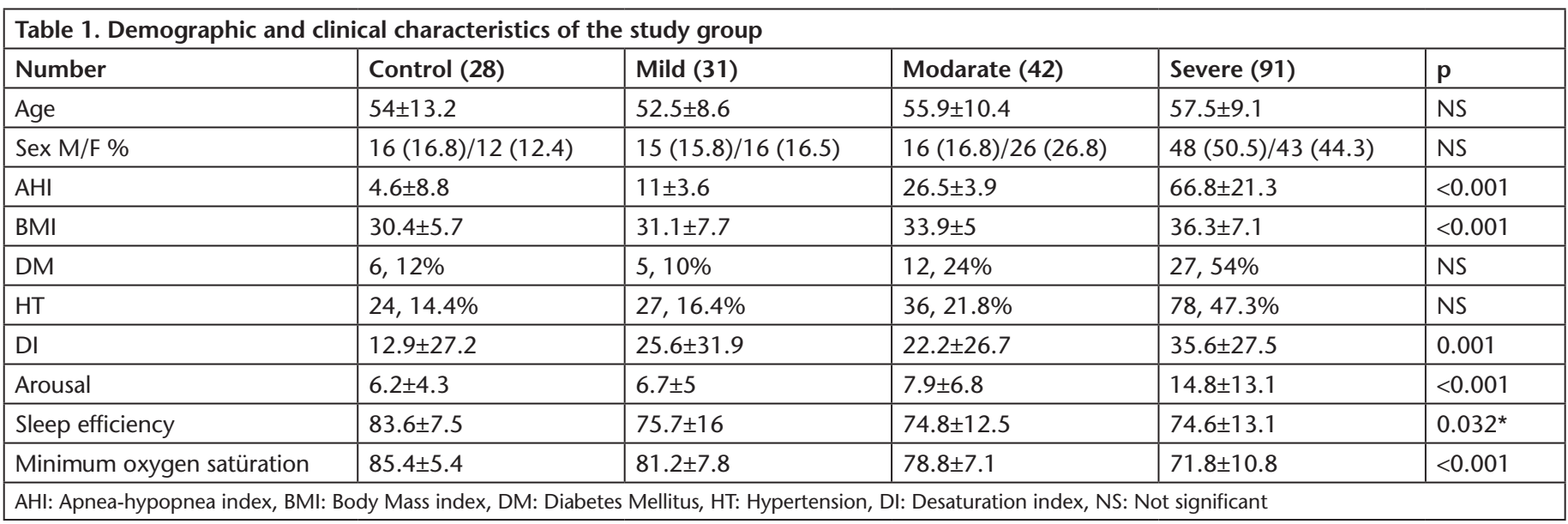

\begin{tabular}{|l|l|l|l|l|l|}
\hline Table 2. Laboratory parameters & Control & Mild & Modarete & Severe \\
\hline & $10.2 \pm 0.9$ & $10.3 \pm 1$ & $10.3 \pm 0.9$ & $10.3 \pm 0.9$ \\
\hline MPV level (fl) & $14.1 \pm 1.2$ & $14.2 \pm 1.7$ & $13.9 \pm 1.6$ & $13.5 \pm 2.4$ & NS \\
\hline Hemoglobin level g/dL & $7.5 \pm 1.5$ & $8.2 \pm 1.5$ & $7.4 \pm 1.4$ & NS & $7.8 \pm 1.8$ \\
\hline WBC count $\left(\times 10^{9} / \mathrm{L}\right)$ & $246.4 \pm 65.5$ & $276 \pm 89.8$ & $260.6 \pm 65.1$ & $269.1 \pm 74.4$ & NS \\
\hline PLT count $\left(\times 10^{9} / \mathrm{L}\right)$ & $42.4 \pm 3.5$ & $43.2 \pm 4.9$ & $42 \pm 3.9$ & $42.2 \pm 5$ & NS \\
\hline Hemotocrit & $84.2 \pm 4.1$ & $82.6 \pm 5.9$ & $83.5 \pm 4.8$ & $81.7 \pm 12.3$ \\
\hline MCV & MPV: Mean platelet volume, WBC: White blood cell, PLT: Platelet, MCV: Mean corpuscular volume, NS: Not significant & NS \\
\hline
\end{tabular}


increased in patients with OSAS in their study. Sympathetic overactivity induce platelet activation via catecholamines. Also hypoxia acute and/or chronically, effects directly platelet functions. Excessive secretion of IL-6 and other pro-inflammatory cytokines by chronic inflammation; act an important role in platelet production and activation in OSAS patients (14). Several studies showed the increased platelet activation and tendency to aggregation in patients with OSAS $(3-6,15-18)$. MPV is an independent risk factor for both the disease severity and inflammation in OSAS patients. There are limited studies that analyzes the relationship between OSAS and MPV levels (2-6). MPV is an indicator for platelet functions and acts an important role in the mechanism of CVD diseases $(19,20)$.

OSAS is an important risk for cardiovascular pathologies and hypertension. Kanbay et al. (2) showed in their study that MPV levels were increased while the severity of OSAS increased. And they pointed out that prevalance of CVD was high in patients with high MPV levels in severe-moderate-mild OSAS patients. Large platelets due to their high granules are able to carry out their own functions more effectively. Increased platelet volume seems to be responsible for increased platelet activation (2). Endler et al. (21) found in their study that increased MPV values, in preexisting Coronary Artery disease formed higher risk for myocardial infarction. Coban et al. (22) showed in their study the increased MPV levels in hypertensive participants.

Varol et al. (6) showed in their study that MPV values of severe OSA patients were significantly higher than controls and there was a correlation with MPV, AHI and DI. Geiser et al. (3) showed the increased in vivo platelet activation in OSA patients during sleep. Esen et al. (23) found in their study that; MPV levels were significanty decreased after continuous positive airway pressure treatment in severe OSAS patients. Additional to MPV levels Akyol et al. (8) studied high-sensitivity $C$ reactive protein (Hs-CRP) levels in their patients. This increased Hs-CRP levels confirms the activated inflammation reactions of platelets in OSAS patients (8).

In our study MPV levels did not differ between groups (control group 10.2 \pm 0.9 , mild group $10.3 \pm 1$, moderate group $10.3 \pm 0.9$ and the severe group $10.3 \pm 0.9)(p=0.993)$. There were no significant differences between groups with respect to white blood cells, $\mathrm{Hb}$, platelet count, MCV and hematocrit values. Karakaş et al. (1) studied the MPV levels in OSAS patients without hypertension, smoking history, diabetes, hyperlipidemia. They divided their patients according to the severity of OSAS into three group and searched whether there was any correlation between MPV and severity of disease. Karakaş et al., (1) found MPV levels higher in patients with severe OSAS than in the control group. They found no significant differences between controls and patients with mild and moderate OSAS group.

Kurt et al. (24) studied 98 patients in their study. They measured $\mathrm{Hb}$, red cell distribution width, MPV, PDW and WBC in their patients. They divided their patients into four groups according to the AHI. They reached that MPV values did not differ between groups. They found higher PDW levels in their severe OSAS group.
Rangemark et al. (25) and Sanner et al. (10) could not found any differences in platelet aggregability and OSAS degree in their studies.

\section{Conclusions}

In conclusion despite our large study group we could not show statistically significant difference in MPV levels according to the OSAS severity and its relationship with cardivascular morbidity. Our results are parallel to Rangemark et al. (25), Sanner et al. (10), Kurt et al. (24), opposite to the studies that found high MPV values in their OSAS groups.

\section{Ethics}

Ethics Committee Approval: The study was created after the ethics committee approval by Malatya Clinical Research Ethics Committee.

Informed Consent: Retrospectively.

Peer-review: Internally peer-reviewed.

Financial Disclosure: The authors declared that this study received no financial support.

\section{References}

1. Karakaş MS, Altekin RE, Baktır AO, Küçük M, Cilli A, Yalçınkaya S. Association between mean platelet volume and severity of disease in patients with obstructive sleep apnea syndrome without risk factors for cardiovascular disease. Turk Kardiyol Dern Ars 2013;41:14-20.

2. Kanbay A, Tutar N, Kaya E, Buyukoglan H, Ozdogan N, Oymak FS, Gulmez I, Demir R. Mean platelet volume in patients with obstructive sleep apnea syndrome and its relationship with cardiovascular diseases. Blood Coagul Fibrinolysis 2013;24:532-6.

3. Geiser T, Buck F, Meyer B], Bassetti C, Haeberli A, GuggerM. In vivo platelet activation is increased during sleep in patients with obstructive sleep apnea syndrome. Respiration 2002;69:229-34.

4. Hui DS, Ko FW, Fok JP, Chan MC, Li TS, Tomlinson B, Cheng $G$. The effects of nasal continuous positive airway pressure on platelet activation in obstructive sleep apnea syndrome. Chest 2004; 125:1768-75.

5. Minoguchi K, Yokoe T, Tazaki T, Minoguchi H, Oda N, Tanaka A, Yamamoto M, Ohta S, O'Donnell CP, Adachi M. Silent brain infarction and platelet activation in obstructive sleep apnea. Am J Respir Crit Care Med 2007; 175:612-7.

6. Varol E, Ozturk O, Gonca T, Has M, Ozaydin M, Erdogan D, Akkaya A. Mean platelet volume is increased in patients with severe obstructive sleep apnea. Scand J Clin Lab Invest 2010;70:497-502.

7. Garvey JF, Taylor CT, McNicholas WT. Cardiovascular disease in obstructive sleep apnoea syndrome: the role of intermittent hypoxia and inflammation. Eur Respir J 2009;33:1195-205.

8. Akyol S, Çörtük M, Baykan AO, Kiraz K, Börekçi A, Şeker T, Gür $M$, Çayli M. Mean platelet volume is associated with disease severity in patients with obstructive sleep apnea syndrome. Clinics (Sao Paulo) 2015;70:481-5.

9. McNicholas WT, Bonsigore MR; Management Committee of EU COST ACTION B26. Sleep apnoea as an independent risk factor for cardiovascular disease: current evidence, basic mechanisms and research priorities. Eur Respir J 2007;29:156-78.

10. Sanner BM, Konermann M, Tepel M, Groetz J, Mummenhoff C, Zidek W. Platelet function in patients with obstructive sleep apnoea syndrome. Eur Respir J 2000;16:648-52. 
11. Martin JF, Trowbridge EA, Salmon GL, Plumb J. The biological significance of platelet volume: its relationship to bleeding time, platelet thromboxane B2 production and megakaryocyte nuclear DNA concentration. Thromb Res 1983;32:443-60.

12. Giles H, Smith RE, Martin JF. Platelet glycoprotein lib-Illa and size are increased in acute myocardial infarction. Eur J Clin Invest 1994;24:69-72.

13. Jakubowski JA, Thompson CB, Vaillancourt R, Valeri CR, Deykin $D$. Arachidonic acid metabolism by platelets of differing size. $\mathrm{Br}$ Haematol 1983;53:503-11.

14. Nena E, Papanas N, Steiropoulos P, Zikidou P, Zarogoulidis P, Pita E, Constantinidis TC, Maltezos E, Mikhailidis DP, Bouros D. Mean Platelet Volume and Platelet Distribution Width in non-diabetic subjects with obstructive sleep apnoea syndrome: new indices of severity? Platelets 2012;23:447-54.

15. Bokinsky G, Miller M, Ault K, Husband P, Mitchell J. Spontaneous platelet activation and aggregation during obstructive sleep apnea and its response to therapy with nasal continuous positive airway pressure. A preliminary investigation. Chest 1995;108:625-30.

16. Eisensehr I, Ehrenberg BL, Noachtar S, Korbett K, Byrne A, McAuley A, Palabrica T. Platelet activation, epinephrine, and blood pressure in obstructive sleep apnea syndrome. Neurology 1998;51:188-95.

17. von Kanel R, Dimsdale JE. Hemostatic alterations in patients with obstructive sleep apnea and the implications for cardiovascular disease. Chest 2003; 124:1956-67.

18. Akinnusi ME, Paasch LL, Szarpa KR, Wallace PK, El Solh AA. Impact of nasal continuous positive airway pressure therapy on markers of platelet activation in patients with obstructive sleep apnea. Respiration 2009;77:25-31.

19. Tsiara S, Elisaf M, Jagroop IA, Mikhailidis DP. Platelets as predictors of vascular risk: is there a practical index of platelet activity? Clin Appl Thromb Hemost 2003;9:177-90.

20. Park Y, Schoene N, Harris W. Mean platelet volume as an indicator of platelet activation: methodological issues. Platelets. 2002;13:301-6.

21. Endler $G$, Klimesch $A$, Sunder-Plassmann $H$, Schillinger $M$, Exner M, Mannhalter C, Jordanova N, Christ G, Thalhammer R, Huber $\mathrm{K}$, Sunder-Plassmann R. Mean platelet volume is an independent risk factor for myocardial infarction but not for coronary artery disease. Br J Haematol 2002;117:399-404.

22. Coban E, Yazicioglu G, Berkant Avci A, Akcit F. The mean platelet volume in patients with essential and white coat hypertension. Platelets 2005; 16:435-8.

23. Esen E, Özdoğan F, Özel HE, Yılmaz Z, Yüce T, Başer S, Genç S, Selçuk A. Mean platelet volume play a role in disease severity in patients with obstructive sleep apnea syndrome? Kulak Burun Bogaz lhtis Derg 2015;25:343-5.

24. Kurt OK, Yildiz N. The importance of laboratory parameters in patients with obstructive sleep apnea syndrome. Blood Coagul Fibrinolysis 2013;24:371-4.

25. Rangemark C, Hedner JA, Carlson JT, Gleer up G, Winther K. Platelet function and fibrinolytic activity in hypertensive and normotensive sleep apnea patients. Sleep 1995;18:188-94. 